\title{
Participation Action Research on Daily Health Literacy Using Voice Recognition Application for the Visual Impairment in Indonesia: A Research Protocol
}

\author{
Mesra Rahayu ${ }^{1,2 *}$, Muhammad Syafar ${ }^{3}$, Razak Thaha ${ }^{4}$, Nurhaedar Jafar $^{4}$, Sudirman Natsir ${ }^{3}$, Intan Sari Areni ${ }^{5}$, \\ Dwia Aries Tina Pulubuhu ${ }^{6}$, Abdul Kadir $^{7}$ \\ ${ }^{1}$ Post Graduate Studies, Public Health Faculty, Hasanuddin University, Makassar, Indonesia; ${ }^{2}$ Department of Pharmacy, Faculty of \\ Pharmacy, Hospital Technology and Information Technology, Megarezky University, Makassar, Indonesia; ${ }^{3}$ Department of Health \\ Promotion, Public Health Faculty, Hasanuddin University, Makassar, Indonesia; ${ }^{4}$ Department of Health Nutrition, Public Health \\ Faculty, Hasanuddin University, Makassar, Indonesia; ${ }^{5}$ Department of Electro Engineering, Engineering Faculty, Hasanuddin \\ University, Makassar, Indonesia; ${ }^{6}$ Department of Sociology, Social Science and Political Science Faculty, Hasanuddin University, \\ Makassar, Indonesia; ${ }^{7}$ General Director of Health Services, Ministry of Health of the Republic of Indonesia, Jakarta, Indonesia
}

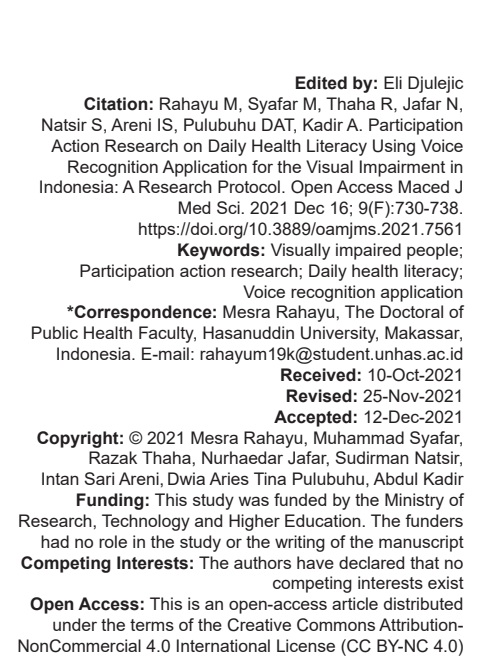

\section{Abstract}

Visually impaired people are often associated with various complex problems because they are considered unproductive even for daily health, so that daily health literacy is needed. The most needed aspects for visually impaired people are balanced nutrition, covid-19, and information on the nearest health service. The location of the difference in health literacy between people who see and people with visual impairment is accessibility. The purpose of this study is to describe the Participation Action Research (PAR) Protocol on Daily Health Literacy Using Voice Recognition Applications for visually impaired people in Indonesia. We will conduct a study using the Mixed Exploratory method, which is a method that in the early stages of research uses qualitative methods and the next stage uses quantitative methods. The mixing of the data of the two methods is connecting between the results of the first and subsequent studies. This exploratory type is a sequential model (sequence). The research stages are divided into three starting from pre-intervention by conducting systematic reviews, preliminary studies, and qualitative studies, as well as application design, the second stage is intervention through two groups, namely, the intervention group carried out health literacy using voice recognition applications and the control group carried out intervention using e-mail. -book reader, the intervention is continued with assistance for the blind by partners for 30 days, the third stage is post-intervention by monitoring and evaluating behavior, and evaluating applications for evolution and publication of applications to the play store for use by visually impaired people in Indonesia.

\section{Introduction}

Disability is a Human Rights issue (UNCRPD) [1], [2]. All relevant sectors should be involved in solving disability access problems, both in the social, health, technical fields, as well as stakeholders, especially government institutions that are in direct contact with policies for solving accessibility problems for people with visual impairments [1]. The difference in health literacy between blind and visually impaired people is accessibility. This is the root of the problem why until now people with visual impairment are still far behind from seeing people. Every health literacy media that is made for people to see should also be made accessible for people with visual impairments. Most of the daily health problems in government programs since 2014 are known as balanced nutrition, this has not been fully accessed by visually impaired people at this time [3].

Blind disease in Indonesia, occupies the second position in the world. Of the total world population who are blind, 3.5 million are Indonesians [4]. The percentage of visually impaired people who have normal nutritional status is lower, namely $59.1 \%$ versus $63.1 \%$ [5], [6], [7], and Jhon (2017) stated that only 33\% of the total blind respondents had good dental and oral hygiene [8]. Another issue related to physical activity, most of the blind do not exercise regularly with $74.2 \%$ [9]. Visually impaired people tend to take $26 \%$ fewer steps per day and spend $48 \%$ less time on physical activity compared to sighted people [10]. During the coronavirus disease pandemic in 2019 (Covid-19), it was also found that only $51.7 \%$ of visually impaired people regularly wash their hands and most of them find it difficult to 
keep their distance from other people (86.2\%) [11]. In the current pandemic emergency, vulnerable groups such as people with visual impairments really need special attention in order to be able to fortify themselves from Covid-19 [12].

Visually impaired people are vulnerable group who have a high mental block. Mental block is the same as limiting belief or lack of confidence and is a mental psychological barrier that covers the minds of Blind Persons due to negative programs in it. Mental Block is strongly influenced by self-acceptance and the environment of the Blind Person. People with visual impairments have mental burdens, such as the fear of meeting new people, the fear of seeing the outside world, the fear of receiving new information, and being ashamed of their limitations. This makes visually impaired people seem passive, because it is difficult to interact with people who are considered foreign to them. The community-based approach is part of PAR that is carried out to establish good cooperation and break the mental block of the blind before, during, and after the study [13]. The community-based approach is proven in solving mental block problems for people with visual impairments [13].

The purpose of this study is to describe the Participation Action Research (PAR) Protocol on Daily Health Literacy Using Voice Recognition Applications for visually impaired people in Indonesia.

\section{Method}

\section{Location}

Grouping starts from determining the location. The location of this research covers a national scale. Then it is divided into three major regions, namely Eastern Indonesia with 18 provinces, Central Indonesia with 12 provinces, and Western Indonesia with four provinces. The total number of provinces in Indonesia is 34 provinces. Sampling in this study is in a gradual cluster (Multistage random sampling) through the following steps:

\section{Location analysis}

Location analysis using probability sampling technique using proportionate stratified random sampling. Proportionate stratified random sampling is a technique used when the population has elements that are not homogeneous and stratified proportionally. To determine the size of the sample in each class, proportional allocation is carried out so that the sample taken is more proportional. Hence, we get four provinces representing Western Indonesia (Sumatra, East Java, West Java, DIY) three provinces representing Central
Indonesia, and one province representing Eastern Indonesia, a total of eight provinces.

\section{institution \\ Selection of the location of the blind}

The selection of the Blind Institution uses a non-random (non-probability) sampling technique through the purposive sampling method, with the criteria of selecting the largest institution/foundation (having the highest number of fostered people) and a city with better guidance and education/exposure to technology, so that the three largest blind foundations/institutions from eight provinces have been determined.

\section{Determining the location of intervention and control}

Determination of the location of intervention and control by looking at the three largest foundations and adding three foundations in the same or nearby areas that have similar characteristics. Furthermore, random locations were conducted and three institutions and three similar blind institutions were obtained interventions in the same area as controls. Overall, the research was conducted in four areas, namely:

\section{Makassar}

1. The Indonesian Blind Development Foundation (YAPTI) Makassar conducted a feasibility test for the application

2. Yayasan Usaha Karya for the Blind Indonesia (YUKARTUNI) Makassar.

\section{Eastern Indonesia (Manado)}

1. Social Rehabilitation Center for Persons with Sensory and Blind Disabilities (BRSPDSN) Tumou Tou Manado (intervention)

2. Bartemeus Blind Mansion Manado (control).

\section{Central Indonesia (Bali)}

1. Social Rehabilitation Center for Persons with Sensory and Blind Disabilities (BRSPDSN) Mahatmiya Bali (intervention)

2. Dria Education Foundation - Raba Denpasar City (control).

\section{Western Indonesia (Bandung and Bekasi)}

1. Social Rehabilitation Center for People with Blind Disabilities (BRSPDSN) Wyata Guna, Bandung, West Java (intervention)

2. Social Rehabilitation Center for Persons with Blind Sensory Disabilities (BRSPDSN) Tan Miyat Bekasi (control) 


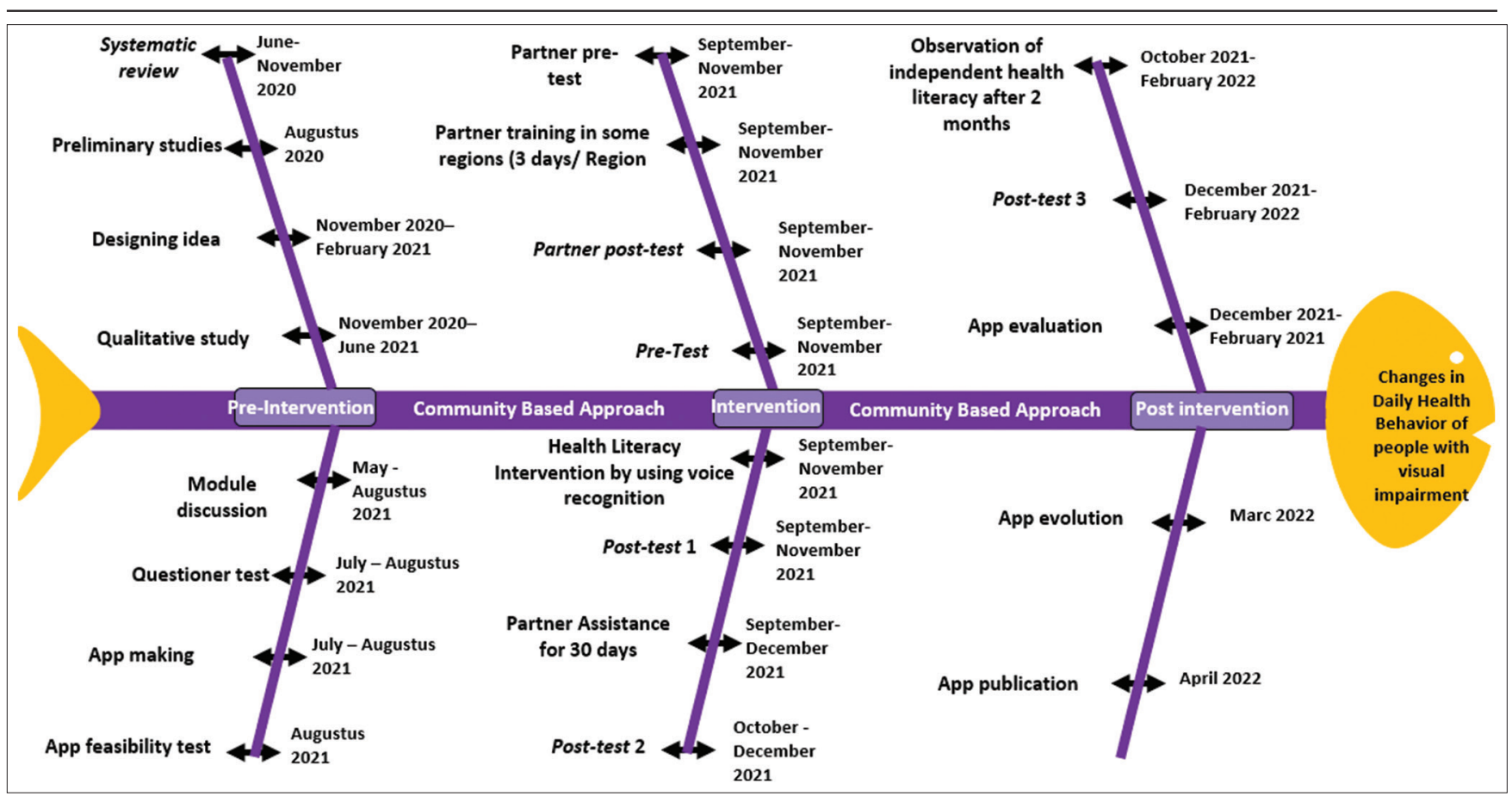

Figure 1: Research timeline

\section{Times}

The research time is made in the form of a skeleton or fishbone sketch designed by the researcher as a research plan. The research was carried out from June 2020 to June 2022 (Figure 1).

\section{Study design}

The design of this study used a "quasiexperimental," randomized experimental design. Randomized experimental design or randomized experimental design or the one that provides the highest level of causal validity which is characterized by the selection of research subjects conducted randomly in both the intervention and control groups [14]. This research requires a community-based approach before, during, and even after the study through co- design Participation Action Research (PAR). PAR is divided into three groups namely Participation, Action, and Research, which are explained along with the following (Figure 2).

\section{Participation}

Participation means taking a role in research activities or activities. Participation emphasizes collective inquiry and collaborative experimentation. There are three collaborations in this research, namely, collaboration between disciplines (public health sciences, information technology, social sciences, disability observers), Collaboration with Stakeholders, Collaboration between Community Elements, and Collaboration between Design Teams.

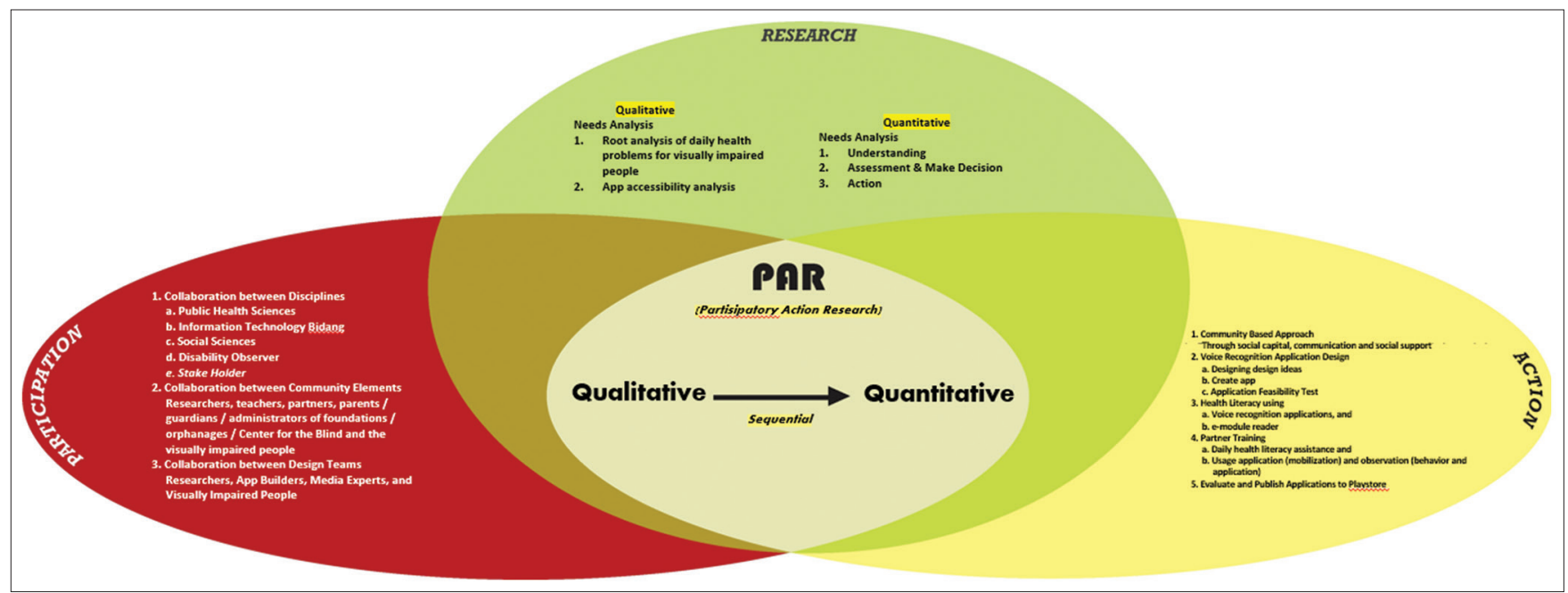

Figure 2: Research design. Source: Exploratory Type Design Modification, [15] and [16] 


\section{Action}

The principle of action requires that all activities in PAR direct the blind to take transformative actions that change their social conditions for the better. Therefore, PAR must contain a clear, scheduled, and concrete change action agenda. Actions include communitybased approaches, application design, health literacy, partner training, and application evaluation and publication.

\section{Research}

This research uses qualitative and quantitative research. Qualitative is used to find the root cause of daily health problems, and accessibility issues. While quantitative research is used to analyse changes in knowledge, attitudes, and actions before and after daily health literacy interventions using voice recognition applications, as well as observation of independent actions for people with visual impairment (Table 1).

The research phase includes three stages, namely the pre-intervention stage, the intervention stage, and the post-intervention stage (a more detailed explanation is in the narrative of the research flow) including:

\section{Pre-intervention stage}

Pre-intervention started from systematic review, community-based approach, preliminary study, designing design ideas, qualitative study, module discussion, questionnaire test, application development, and application feasibility test, so that the application is feasible to be used as a health literacy media.

\section{Intervention stage}

The intervention phase starts again with a community-based approach, partner training for 3 days, pre-test, health literacy intervention for the blind using voice recognition applications for 3 days, Post-test 1 , Partner Mentoring for 30 days, Posttest 2.

\section{Post-intervention stage}

Post-intervention was carried out by independent health literacy observation for 2 months, post-test 3, application evaluation, application evolution, and application publication.

\section{Sample size}

The sample size was based on detecting a difference in outcome variable of $10 \%$ between intervention and control group. To detect this difference 54 respondents in each of group is needed (assuming a common standard deviation (SD) of 16 , power $=95 \%$, alpha level=0.05). We plan to recruit 108 respondents for total respondents.

\section{Recruitment and data collection}

The target in this study uses the population, informants for qualitative studies and samples to be used as respondents in quantitative research which are described as follows:

\section{Population}

The population in this study were all visually impaired people in Indonesia who were fostered at blind institutions/foundations, at selected locations, namely as many as 457 people.

\section{Informants}

Determination of informants, the main informants in this study are the Blind Persons who are fostered at the Foundation/Development Center. The informant selection technique used purposive sampling technique with criteria;

1. Informants are individuals with total blindness and low vision who do not have other disabilities, such as deaf or quadriplegic, etc.

2. Informants are visually impaired people who are fostered in foundations/institutions and actively participate in coaching

3. Being free from a strong mental block is characterized by a willingness to be interviewed and participate in a whole series of research.

\section{Exclusion criteria}

1. Visually impaired people who are not in the selected foundation/guidance center

2. Have double disability

3. Not willing to be interviewed and not willing to take part in the whole series of research

4. Respondents sick during research

5. Respondents did not follow the intervention carried out.

Based on the criteria, a qualitative research will be conducted at YUKARTUNI with 35 informants who meet the requirements for blind informants. Then look for supporting informants with the following criteria:

1. Are partners/teachers/parents/managers of centers or foundations, who have known visually impaired persons for more than 1 year

2. Willing to be interviewed

3. Located in the research area where the application feasibility test was carried out, and located in the representative areas of East, Central, and West Indonesia, which were selected locations. 
Table 1: Matrix of data collection methods on the effect of android-based daily health literacy with blind behavior changes in Indonesia

\begin{tabular}{|c|c|c|c|c|c|c|c|c|c|c|}
\hline \multirow[t]{3}{*}{ Data types data } & \multirow[t]{3}{*}{ Variables } & \multirow[t]{3}{*}{ Informants } & \multicolumn{6}{|c|}{ Data collection methods } & \multirow{3}{*}{$\begin{array}{l}\text { Methods } \\
\text { of data } \\
\text { collection }\end{array}$} & \multirow[t]{3}{*}{ Information } \\
\hline & & & \multicolumn{3}{|c|}{ Qualitative } & \multicolumn{3}{|c|}{ Quantitative } & & \\
\hline & & & WM & Observer & FGD & Quest & Intervention & $\begin{array}{l}\text { Observation/ } \\
\text { Evaluation }\end{array}$ & & \\
\hline 1 & 2 & 4 & 5 & 6 & 7 & 8 & 9 & 10 & 11 & 12 \\
\hline \multirow[t]{2}{*}{ I. Characteristics } & \begin{tabular}{l} 
1. Education \\
2. Gender \\
3. Age \\
4. Ethnicity \\
5. Language \\
6. Type of visual \\
\multicolumn{1}{c}{ impairments }
\end{tabular} & $\begin{array}{l}\text { Key informants } \\
\text { are people with } \\
\text { Visual Impairment } \\
\text { and supporting } \\
\text { informants (Chairman } \\
\text { of the Foundation) }\end{array}$ & $\sqrt{ }$ & $\mathrm{x}$ & $x$ & $x$ & $x$ & $\mathrm{X}$ & $\begin{array}{l}\text { Primary and } \\
\text { secondary } \\
\text { data }\end{array}$ & $\begin{array}{l}\text { Secondary data was } \\
\text { obtained through the } \\
\text { chairman of the foundation } \\
\text { and primary data was taken } \\
\text { through People with visual } \\
\text { impairment }\end{array}$ \\
\hline & $\begin{array}{l}\text { 1. Education } \\
\text { 2. Gender } \\
\text { 3. Age } \\
\text { 4. Ethnicity } \\
\text { 5. Language } \\
\text { 6. Type of support }\end{array}$ & $\begin{array}{l}\text { Supporting } \\
\text { informant (Partners/ } \\
\text { Family (Foundation } \\
\text { Boards)/Management } \\
\text { Institution/hall/ } \\
\text { teachers) }\end{array}$ & $\mathrm{x}$ & $\mathrm{x}$ & $\sqrt{ }$ & $x$ & $x$ & $x$ & Primary data & $\begin{array}{l}\text { The data were collected in } \\
\text { each area surveyed, a total } \\
\text { of } 1 \mathrm{FGD} \text { ( } 6 \text { people) }\end{array}$ \\
\hline \multirow[t]{7}{*}{$\begin{array}{l}\text { II. Media Design } \\
\text { (Android-based } \\
\text { application using } \\
\text { voice recognition) }\end{array}$} & 1. Needs analysis & $\begin{array}{l}\text { People with visual } \\
\text { impairment fostered } \\
\text { by YAPTI and } \\
\text { YUKARTUNI } \\
\text { Makassar } \\
\text { Partners/ } \\
\text { Family (Foundation } \\
\text { Boards)/Management } \\
\text { Institution/hall/ } \\
\text { teachers }\end{array}$ & $\sqrt{ }$ & $x$ & $\sqrt{ }$ & $\mathrm{x}$ & $x$ & $\mathrm{X}$ & Primary data & $\begin{array}{l}\text { The data were collected } \\
\text { from People with visual } \\
\text { impairment fostered by } \\
\text { YAPTI and YUKARTUNI } \\
\text { Makassar } \\
\text { The data were collected in } \\
\text { each area surveyed, a total } \\
\text { of } 1 \text { FGD ( } 6 \text { people) }\end{array}$ \\
\hline & 2. Idea design & $\begin{array}{l}\text { Key informant, } \\
\text { supporting informant, } \\
\text { and expert informant }\end{array}$ & $\sqrt{ }$ & $\mathrm{x}$ & $\sqrt{ }$ & $\mathrm{x}$ & $x$ & $x$ & Primary data & $\begin{array}{l}\text { Idea design was obtained } \\
\text { from analysis of the } \\
\text { qualitative study and the } \\
\text { results of literature Review } \\
\text { with PAR approach }\end{array}$ \\
\hline & 7. App making & $\begin{array}{l}\text { The Researcher, the } \\
\text { expert team, and the } \\
\text { design team }\end{array}$ & $\mathrm{x}$ & $x$ & $x$ & $x$ & $x$ & $x$ & Primary data & $\begin{array}{l}\text { The result of discussion } \\
\text { with a team of experts } \\
\text { and data analysis design } \\
\text { team created a joint } \\
\text { application (application as } \\
\text { intervention tool) }\end{array}$ \\
\hline & $\begin{array}{l}\text { 4. App Feasibility } \\
\text { Test }\end{array}$ & $\begin{array}{l}\text { People with } \\
\text { visual impairment } \\
\text { fostered by YAPTI } \\
\text { and YUKARTUNI } \\
\text { Makassar }\end{array}$ & $\mathrm{x}$ & $\mathrm{x}$ & $\mathrm{x}$ & $\mathrm{x}$ & $\mathrm{x}$ & $\sqrt{ }$ & Primary data & $\begin{array}{l}\text { App feasibility test was } \\
\text { conducted in YAPTI } \\
\text { Makassar (Pre-intervention } \\
\text { evaluation sheet) }\end{array}$ \\
\hline & $\begin{array}{l}\text { 5. Mobilization and } \\
\text { Monitor }\end{array}$ & $\begin{array}{l}\text { The researcher and } \\
\text { the expert media }\end{array}$ & $x$ & $\sqrt{ }$ & $\mathrm{x}$ & $\mathrm{x}$ & $\mathrm{x}$ & $\sqrt{ }$ & Primary data & $\begin{array}{l}\text { The mobilization used } \\
\text { the application tool in } \\
\text { intervention throughout the } \\
\text { study areas, while monitoring } \\
\text { was conducted by observing } \\
\text { the ability of People with } \\
\text { visual impairment in the } \\
\text { whole area of research by } \\
\text { using observation sheet } \\
\text { application }\end{array}$ \\
\hline & $\begin{array}{l}\text { 6. Evaluation and } \\
\text { Evolution }\end{array}$ & $\begin{array}{l}\text { People with visual } \\
\text { impairment and } \\
\text { Partners s }\end{array}$ & $x$ & $\mathrm{x}$ & $\mathrm{x}$ & $x$ & $x$ & $\sqrt{ }$ & Primary data & $\begin{array}{l}\text { The evaluation was } \\
\text { carried out by observing } \\
\text { the accessibility of using } \\
\text { the application, and } \\
\text { received suggestions } \\
\text { for improvements if } \\
\text { needed for people with } \\
\text { visual impairment and } \\
\text { partners (post-intervention) }\end{array}$ \\
\hline & 7. Publications & $\begin{array}{l}\text { The Researcher and } \\
\text { the Design Team }\end{array}$ & $x$ & $x$ & $\mathrm{x}$ & $x$ & $x$ & $x$ & Primary data & $\begin{array}{l}\text { An application was } \\
\text { published to the PlayStore } \\
\text { platform to be used } \\
\text { by people with visual } \\
\text { impairment }\end{array}$ \\
\hline \multirow{4}{*}{$\begin{array}{l}\text { III. Intervention } \\
\text { Literacy } \\
\text { Health Day } \\
\text { Android-Based } \\
\text { applications using } \\
\text { Voice Recognition } \\
\text { IV. Daily Health } \\
\text { Behavior ofpeople } \\
\text { with visual } \\
\text { impairment }\end{array}$} & 1. Intervention group & $\begin{array}{l}\text { People with visual } \\
\text { impairment }\end{array}$ & $x$ & $x$ & $x$ & $\mathrm{x}$ & $\sqrt{ }$ & $x$ & - & $\begin{array}{l}\text { Daily health literacy } \\
\text { interventions used voice } \\
\text { recognition applications }\end{array}$ \\
\hline & 2. Control group & $\begin{array}{l}\text { People with visual } \\
\text { impairment }\end{array}$ & $\mathrm{x}$ & $\mathrm{x}$ & $\mathrm{x}$ & $x$ & $\sqrt{ }$ & $x$ & - & $\begin{array}{l}\text { Daily health literacy } \\
\text { interventions used an } \\
\text { e-reader module }\end{array}$ \\
\hline & $\begin{array}{l}\text { 1. Awareness } \\
\text { (Understanding) }\end{array}$ & $\begin{array}{l}\text { People with visual } \\
\text { impairment }\end{array}$ & $x$ & $\mathrm{x}$ & $\mathrm{x}$ & $\sqrt{ }$ & $\sqrt{ }$ & $x$ & Primary data & $\begin{array}{l}\text { The Knowledge for people } \\
\text { with visual impairment was } \\
\text { measured before and after } \\
\text { the intervention, one month } \\
\text { after mentoring, and } 2 \\
\text { months after independence }\end{array}$ \\
\hline & & Partners & $\mathrm{x}$ & $\mathrm{x}$ & $\mathrm{x}$ & $\sqrt{ }$ & $\sqrt{ }$ & $x$ & Primary data & $\begin{array}{l}\text { The Knowledge of Partners } \\
\text { was only measured before } \\
\text { and after the training } \\
\text { partners s }\end{array}$ \\
\hline
\end{tabular}


Table 1: (Continued)

\begin{tabular}{|c|c|c|c|c|c|c|c|c|c|c|}
\hline \multirow[t]{3}{*}{ Data types data } & \multirow[t]{3}{*}{ Variables } & \multirow[t]{3}{*}{ Informants } & \multicolumn{6}{|c|}{ Data collection methods } & \multirow{3}{*}{$\begin{array}{l}\text { Methods } \\
\text { of data } \\
\text { collection }\end{array}$} & \multirow[t]{3}{*}{ Information } \\
\hline & & & \multicolumn{3}{|c|}{ Qualitative } & \multicolumn{3}{|c|}{ Quantitative } & & \\
\hline & & & WM & Observer & FGD & Quest & Intervention & $\begin{array}{l}\text { Observation/ } \\
\text { Evaluation }\end{array}$ & & \\
\hline & $\begin{array}{l}\text { 2. Attitude (Asses } \\
\text { and make decisions) }\end{array}$ & $\begin{array}{l}\text { People with visual } \\
\text { impairment }\end{array}$ & $x$ & $\mathrm{x}$ & $x$ & $\sqrt{ }$ & $\sqrt{ }$ & $\mathrm{x}$ & Primary data & $\begin{array}{l}\text { The attitudes of people with } \\
\text { visual impairment were } \\
\text { measured before and after } \\
\text { the intervention, one month } \\
\text { after mentoring, and } 2 \\
\text { months after independence }\end{array}$ \\
\hline & & Partners & $\mathrm{x}$ & $\mathrm{x}$ & $\mathrm{x}$ & $\sqrt{ }$ & $\sqrt{ }$ & $x$ & Primary data & $\begin{array}{l}\text { The attitudes of partners } \\
\text { were only measured before } \\
\text { and after the training } \\
\text { partners s }\end{array}$ \\
\hline & 3. Action & $\begin{array}{l}\text { People with visual } \\
\text { impairment }\end{array}$ & $x$ & $x$ & $x$ & $\sqrt{ }$ & $\sqrt{ }$ & $\sqrt{ }$ & Primary data & $\begin{array}{l}\text { The action of people with } \\
\text { visual impairment was } \\
\text { measured before and after } \\
\text { the intervention, } 1 \text { month } \\
\text { after mentoring, and } 2 \\
\text { months after independence }\end{array}$ \\
\hline & & Partners & $x$ & $x$ & $x$ & $\sqrt{ }$ & $\sqrt{ }$ & $x$ & Primary data & $\begin{array}{l}\text { The action of Partners was } \\
\text { only measured before and } \\
\text { after training }\end{array}$ \\
\hline & 4. independence (skill) & $\begin{array}{l}\text { People with visual } \\
\text { impairment }\end{array}$ & $x$ & $x$ & $x$ & $x$ & $\mathrm{x}$ & $\sqrt{ }$ & Primary data & $\begin{array}{l}\text { The Independence } \\
\text { of people with Visual } \\
\text { Impairment was observed } 2 \\
\text { months after independence }\end{array}$ \\
\hline & & Partners & $\mathrm{x}$ & $\mathrm{x}$ & $\mathrm{x}$ & $\mathrm{x}$ & $\mathrm{x}$ & $\mathrm{x}$ & - & $\begin{array}{l}\text { Partners were } \\
\text { not measured for } \\
\text { independence because } \\
\text { partners s were research } \\
\text { supporters/companions } \\
\text { only }\end{array}$ \\
\hline
\end{tabular}

Based on these criteria, 1 FGD group will be selected (6 people per research location). Hence, a total of 36 informants.

\section{Sample}

The sample is part of the overall subject under study and is considered to represent the entire population. The minimum sample size is 74 . Hence, the total sample used for each experimental group is 74 blind people. Hence, the total sample of intervention and control is 148 people. After the minimum sample size is known, a proportional sample calculation is carried out to determine the minimum sample that must be met for each research area. The Eastern Indonesia region in the Tumoutou and Bartimaeus regions each has a minimum sample of 18 people. While in Central Indonesia in the areas of Bali, Mahatmia, and Dria Raba (Denpasar) each minimum sample is 17 people, and in West Indonesia in the areas of Tamiat Bekasi and Wiyata Guna Bandung, each sample is at least 40 people.

\section{Grouping procedure}

The study group was divided into two groups: the intervention group was given the Blind Persons with health literacy interventions daily use applications of voice recognition and control groups through the provision of health literacy using the reader files module (e-reader module). The use of the control group in this study as a comparison group where pretest measurements will be carried out in the intervention and control groups to assess the initial comparability of the groups. If the pre-test results in the intervention group are similar to those in the control group, the smaller the probability of confounding variables [17].

In this study, the Pre-Questionnaire will be given to all respondents who are in the foundation during the research considering that basic value equalization will be carried out to see knowledge, attitudes, and initial practice with the same average value before the intervention. This is so that respondents start from the same 0 point. The standard value for being a respondent has the same average value between $45-50 \%$, while being categorized as having a good value for the post-test has a value of $>80 \%$. Respondents who have been equalized and meet the inclusion criteria will be intervened by taking into account the minimum consideration of the sample.

\section{Interventions group}

Before the intervention, a pre-test of knowledge, attitude, and practice was carried out. Furthermore, daily health literacy interventions were given using a voice recognition application with the provision of material for 3 days. After the direct intervention, the first posttest was given to measure knowledge, attitudes, and practices after the intervention. After that, mentoring is carried out by trained partners for 30 days and then given the $2^{\text {nd }}$ post-test, and the blind daily health practices will be observed independently for the next 2 months. The pattern was post-test 1 immediately after education, and post-test 2 conducted 1 month later after mentoring, and post-test 3 after 2 months to measure behavioral changes before and after the intervention. 


\section{Control group}

The intervention and control groups had the same pattern in the daily health literacy intervention. The difference lies in the literacy media used, using voice recognition application (for the intervention group) and e-module reader (for the control group).

\section{Instruments}

Instruments used in this study:

\section{Qualitative}

1. Interview guidelines,

2. Observation sheet

3. FGD sheet,

4. Recording device for the purpose of Analysis of application requirements.

\section{Quantitative}

1. Tested literacy results evaluation instrument (pre post questionnaire)

2. Media expert assessment (Questioner)

3. Interventions require e-modules with standardized Health Literacy Content/Materials and have passed expert reviews

4. Application evaluation instrument

5. The time-tested voice recognition app and

6. Standard operational procedure (sop) for application usage.

\section{Data management}

Data will be checked for consistency and completeness by the principal investigator and double entered to SPSS by experienced data entry clerks. Hard copies of the data will be stored in a locked cabinet and consent forms will be separated from the data.

\section{Data analysis}

Qualitative data analysis using Taxonomy analysis which aims to find the root cause of the daily health needs of Blind Persons and assessing the type and content of the application needed (accessibility) starting from the type of sound, menu type, layout, etc., and finally the researcher can find a complete picture of the object study.

In this study, categorization was carried out, the Cochran test with McNemar post hoc was carried out to analyze differences in knowledge (category: good and bad) and attitudes (category: good and bad), practice (good, bad) in each group between before, after intervention, and 2 months after the intervention. The test uses a $95 \%$ confidence level $(\alpha=0.05)$. To analyze the differences in the Knowledge
(Understanding), Attitude (Assessment), Practice (action) scores between the case group and the control group with more than one measurement (before, after the intervention, and 2 months after the intervention) the General Linear Model test was used with post hoc if the distribution is normal, and the Mann-Whitney test is repeated with corrections if the distribution is not normal. After categorizing these variables, the Generalized estimating equation test was then carried out to analyze differences in knowledge (category: good and bad), attitudes (category: good and bad), and practice (category: good and bad) between the case group and the control group.

\section{Patient and Public involvement}

Patients and/or the public (Blind) are fully involved in every stage of this research, Blind Persons also provide input in all stages of the research to suit their needs, so that research results can be accounted for and accessible.

\section{Ethical Consideration}

Ethics approval for the study issued by the Commission on Health Research Ethics Public Health Faculty of Hasanuddin University with protocol number 14621043012 (see online supplementary file 1). All participants will be informed of the aims and objectives of the study, and confidentiality will be maintained throughout the study. Information and informed consent will be provided at the beginning of the study and participants will be free to withdraw from the program at any time.

\section{Ethical Approval and Consent to Participate}

Ethics approval for the study issued by the Commission on Health Research Ethics Public Health Faculty of Hasanuddin University with protocol number 14621043012. The informed consent of the informants and respondents in this study used informed consent, children under 15 years of age will be accompanied directly by their parents/guardians in filling out the informed consent.

\section{Strength and Limitation}

- This research designs a new information technology that suits the needs of people with visual impairment (user friendly) 
The code design participation action research application with a community-based approach that involves people with visual impairments and the closest social environment for people with visual impairments is expected to be a strategy to hack the mental blocks of people with visual impairments

- $\quad$ Fulfilment of the right of access to health information for people with visual impairments to change the daily health behavior of people with visual impairments so that it is hoped that people with visual impairments have the will and ability to independently perform standardized health behaviors so that it leads to an increase in the highest level of health The application is designed for accessibility with the use of voice recognition, meaning that it can be accessed easily and cheaply, and is efficient for people with visual impairments. So that the consideration of cheap cell phones, short processing times, simple designs according to the capacity/ability of the blind, the use of Indonesian language, simplification of health language content/speech, and applications that will have social purposes because they can be downloaded for free This research produces a product so that in addition to being efficient and according to needs, it can also be seen in real terms and can be used continuously (sustainably)

- $\quad$ Opening inclusive insight about the importance of accessibility and equal rights of equality for all people, both disabled and non-disabled. If this principle is applied then no one is left behind in development, education, and health, including disability

- Multi-sector involvement is needed, both in the social, health, technical, as well as stakeholders, especially institutions that are in direct contact with policies for solving accessibility problems for people with visual impairments. So that it is expected to be a forum for collaboration between scientific disciplines in research

- Participatory research involving visually impaired people like this can only be done by partners who have long known and have emotional closeness with blind people

This research involves many people with a wide area coverage so that it requires a lot of costs in its implementation.

\section{Acknowledgments}

We are grateful for the support from the Faculty of Public Health, Hasanuddin University. We thank the Promoters, co-promoters, examiners, media team, Foundations/Orphanages, Teachers, Partners, Families, and visually impaired people who participated in this research. We also thank friends netra who have assisted in a community-based approach, especially in data collection in the field.

\section{References}

1. Pillay N. Monitoring the Convention on the Rights of Persons with Disabilities: Guidance for Human Rights Monitors, No. 17; 2010. p. 1-67.

2. Date P. EPG Accessibility Annual Report on Improvements for People with Visual Impairments; 2020.

3. Hastuti, Dewi RK, Pramana RP, Sadaly H. Kendala Mewujudkan Pembangunan Inklusif Terhadap Penyandang Disabilitas; 2020.

4. Bourne RR, Flaxman SR, Braithwaite T, Cicinelli MV, Das A, Jonas JB, et al. Magnitude, temporal trends, and projections of the global prevalence of blindness and distance and near vision impairment: A systematic review and meta-analysis. Lancet Glob Health. 2017;5(9):e888-97. https://doi.org/10.1016/ S2214-109X(17)30293-0

5. Das T. Blindness and visual impairment profile and rapid assessment of avoidable blindness in South East Asia: Analysis of new data. 2017 APAO Holmes lecture. Asia Pac J Ophthalmol. 2018;7(5):312-5. https://doi.org/10.22608/APO.2017425 PMid:29532647

6. World Health Organization. DALYs No Title Global Food Safety. Geneva: World Health Organization; 2020.

7. Alshatrat S, Al Bakri I, Al Omari W, Tabnjh A. Oral health knowledge, behaviour, and access to dental care in visually impaired individuals in Jordan: A case-control study. Open Dent J. 2021;15(1):33-40. https://doi. org/10.2174/1874210602115010033

8. John JR, Daniel B, Paneerselvam D, Rajendran G. Prevalence of dental caries, oral hygiene knowledge, status, and practices among visually impaired individuals in Chennai, Tamil Nadu. Int J Dent. 2017;2017:9419648. https://doi. org/10.1155/2017/9419648

PMid:28458691

9. An Y, Joo CK. The U-shaped association between selfreported sleep duration and visual impairment in Korean adults: A population-based study. Sleep Med. 2016;26:30-6. https://doi. org/10.1016/j.sleep.2016.08.005 PMid:28007357

10. Smith L, Jackson SE, Pardhan S, López-Sánchez GF, Hu L, Cao $\mathrm{C}$, et al. Visual impairment and objectively measured physical activity and sedentary behaviour in US adolescents and adults: A cross-sectional study. BMJ Open. 2019;9(4):e027267. https://doi.org/10.1136/bmjopen-2018-027267

11. World Health Organization. No Title Nutrition and Food Safety (NFS) and COVID-19. Geneva: World Health Organization; 2020. https://www.who.int/teams/nutrition-and-food-safety/ covid-19. [Last accessed on 2021 Sep 08].

12. Shalaby WS, OdayappanA, Venkatesh R, Swenor BK, Ramulu PY, Robin AL, et al. The impact of COVID-19 on individuals across the spectrum of visual impairment. Am J Ophthalmol. 2021;227:5365. https://doi.org/10.1016/j.ajo.2021.03.016 PMid:33781768

13. Bodaghi NB, Cheong LS, Zainab AN. Librarians empathy: Visually impaired students' experiences towards inclusion 
and sense of belonging in an academic library. J Acad Librar. 2016;42(1):87-96. https://doi.org/10.1016/j.acalib.2015.11.003

14. Mitchell O. Experimental Research Design. The Encyclopedia of Crime and Punishment; 2015. p. 1-6. https://doi. org/10.1002/9781118519639.wbecpx113

15. Creswell JW. Research Design Qualitative; Quantitative; and Mixed Methods Approaches. $4^{\text {th }}$ ed. Thousand Oaks, California: Sage; 1995.
16. Buckles DJ. Participatory Action Research: Theory and Methods for Engaged Inquiry; 2013. https://doi. org/10.4324/9780203107386

17. Harris AD, McGregor JC, Perencevich EN, Furuno JP, Zhu J, Peterson DE, et al. The use and interpretation of quasiexperimental studies in medical informatics. J Am Med Inform Assoc. 2006;13(1):16-23. https://doi.org/10.1197/jamia.M1749 PMid:16221933 